\title{
Aセッション 日本内科学会生涯教育講演会
}

\section{平成13年度}

\section{I. 消化器 \\ 3. 上部消化管緊急内視鏡検査}

藤本 一貝

Key words：消化管出血, 胃・十二指腸潰湯, 食道・胃静脈溜, 異物誤飲

はじめに

消化管内視鏡検查は以前は診断が主目的であっ たが，内視鏡技術の進歩とともに診断だけでな く内視鏡的治療が可能となってきた，緊急内視 鏡検查において様々な治療が可能となり，その 意義がますます重要になってきている。今回は 上部消化管に限定し，どのような場合に緊急内 視鏡検査がなされ，どのような治療が可能なの かをその成績とともに概説したい.

1. 上部消化管緊急内視鏡検査の適応となる臨床 症状（表 1)

実際にどのような場合に緊急内視鏡を施行す るのであろうか，表 1 に佐賀医科大学附属病院 において過去 10 年間で上部消化管緊急内視鏡検 査を施行した患者 1,491 例の臨床症状をみてみる と，吐血・下血等の消化管出血の症例が 1,085 例であり䝷血等の症状で上部消化管出血を疑っ た 214 例とを併せると全体の $90 \%$ 近くを占めて いる. その他は上腹部痛, 器下困難, 異物誤飲, 等となっている，消化管出血はその多くが内視 鏡的に止血可能となり，異物に関しては内視鏡 的除去が可能となっており, 各施設において積 極的に緊急内視鏡検査が施行されるようになっ ている。

ふじもと かずま：佐賀医科大学内科
表 1. 上部消化管緊急内視鏡検查における主症状(佐 賀医科大学附属病院 1990 年 1999 年)

\begin{tabular}{l|r}
\hline 消化管出血（昍下血） & 1,085 症例 \\
貧血 & 214 症例 \\
腹痛 & 106 症例 \\
嬩下困難 & 13 症例 \\
異物譟創 & 52 症例 \\
その他 & 21 症例 \\
\hline 計 & 1,491 症例 \\
\hline
\end{tabular}

表 2. 上部消化管緊急内視鏡検查での診断（佐賀医科 大学附属病院 1990 年 1999 年)

\begin{tabular}{|c|c|}
\hline 出血性病変 & 1,094 症例 \\
\hline 胃潰瘍 & 367 症例 \\
\hline 十二指腸潰㻛 & 163 症例 \\
\hline 吻合部潰場 & 14 症例 \\
\hline 逆流性食道炎 & 17 症例 \\
\hline 胃炎, 急性雸粘膜病変 & 183 症例 \\
\hline 悪性腫痬 & 55 症例 \\
\hline Mallory-Weiss 症候群 & 54 症例 \\
\hline 食道·胃静脈瘤 & 241 症例 \\
\hline 胃アニサキス症 & 34 症例 \\
\hline 異物詔飲 & 52 症例 \\
\hline その他 & 212 症例 \\
\hline 病変を指摘できず & 99 症例 \\
\hline 計 & 1,491 症例 \\
\hline
\end{tabular}

\section{2. 上部消化管緊急内視鏡検査の診断（表 2）}

消化管出血を疑われて緊急内視鏡検查をする 場合が多く，緊急内視鏡検查では出血性病変が 指摘される場合が多い。佐賀医科大学附属病院 
での消化管出血を疑い上部消化管内視鏡検查を 施行した 1,299 症例においても上部消化管に出血 性病変を確認できた症例は 1,094 例である.ただ, 上部消化管内視鏡検查だけでは出血病变の診断 のつかない場合も少なくない.出血以外の疾患 としてはアニサキス症，異物等がある。アニサ キスは内視鏡的に除去することで患者の腹痛は 改善する，食道や胃にとどまっている異物の多 くは内視鏡的に除去が可能だが，その際の注意 点は食道粘膜や咽喉頭部を損傷しないことであ る.

\section{3. 上部消化管出血性病変}

表 2 に示すように上部消化管の出血性病変で 一番頻度が高いのは潰瘍性病変からの出血であ る. 佐賀医科大学附属病院の例で示すように本 邦では十二指腸潰瘍より胃潰瘍出血のほうが頻 度が高い。これらの疾患に比較すると頻度は少 ないが，逆流性食道炎やMallory-Weiss症侯群か らの出血がみられることもある．潰瘍性病変に 次いで多い出血の原因が食道・胃静脈瘤である. これらの出血性病変に対しては最近ではそのほ とんどが内視鏡的に止血が可能となっている.

\section{4. 出血性病变に対する内視鏡的止血術}

1）出血性胃・十二指腸潰瘍に対する止血術 内視鏡的止血には樣々な方法が用いられてお り，その例を表 3 に示した。本邦で実際によく 用いられている方法は, 純エ夕ノール局所注入, クリップ，ヒートプローブ等であるが，最近ア ルゴンプラズマ凝固法を用いる施設も増えてい る. 局所注入法は簡便であり安価であること， クリップ法は介助者の熟練を要するが確実な止 血が得られること, 凝固法は正面視できない出 血に比較的容易に対応できる，等のそれぞれの 利点があるが，実際にはどの方法でも各施設で 慣れた方法を選べば止血率にはほとんど差がな い. 佐賀医科大学附属病院においてエタノール 局所注入法, クリップ法, 雨者併用の 3 群に無
表 3.内視鏡的止血法

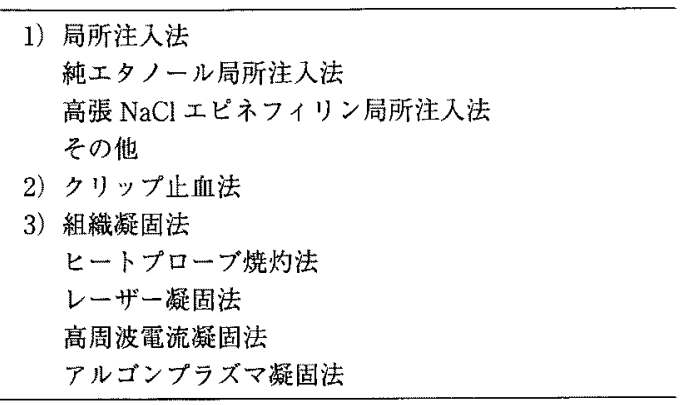

作為に割り付けて比較したがその成績の差はほ とんど認められなかった、いったん䧺実な止血 が得られると $\mathrm{H} 2$ 受容体拮抗剤やプロトンポンプ 阻害剂等の投与や場合によってはピロリ菌の除 菌で速やかな潰蝪の治癒が期待できるようにな $り, 1$ 週間以後の潰瘍の再出血の危険は減ってき ている。

佐賀医科大学附属病院にお括出血性胃濽場 における緊急手術例の年次推移を図 1 に示して いる". 内視鏡的止血術の増加と共に減少してお り，1990年以後はほとんど緊急手術を必要とし なくなっている．内視鏡施行時に出血している 胃潰灌に对しては当然のことながら止血術を施 行するが，それでは内視鏡時に出血してない露 出血管の処置は必要であろうか. 佐賀医科大学 附属病院で施行した無作為前向き試験の成績を 表 4 に示した2). 露出血管に対して純エ夕ノール 局所注入法を施行すると再出血辩は $12.1 \%$ であ るが，トロンビンの局所散布のみでの再出血率 は 34.5\% と高率であった。この結果は再出血子 防のためには露出血管は必ず内視鏡的に処置し ておく必要があることを示している．潰瘍に凝 血塊が付着しているような場合には凝血塊を取 り除いて露出血管の有無の確認し, 露出血管が ある場合には内視鏡的処監をすることが重要で ある。

胃潰瘍の露出血管は積極的に処置をするが， 十二指腸潰瘍では必ずしもそうではない，球部 


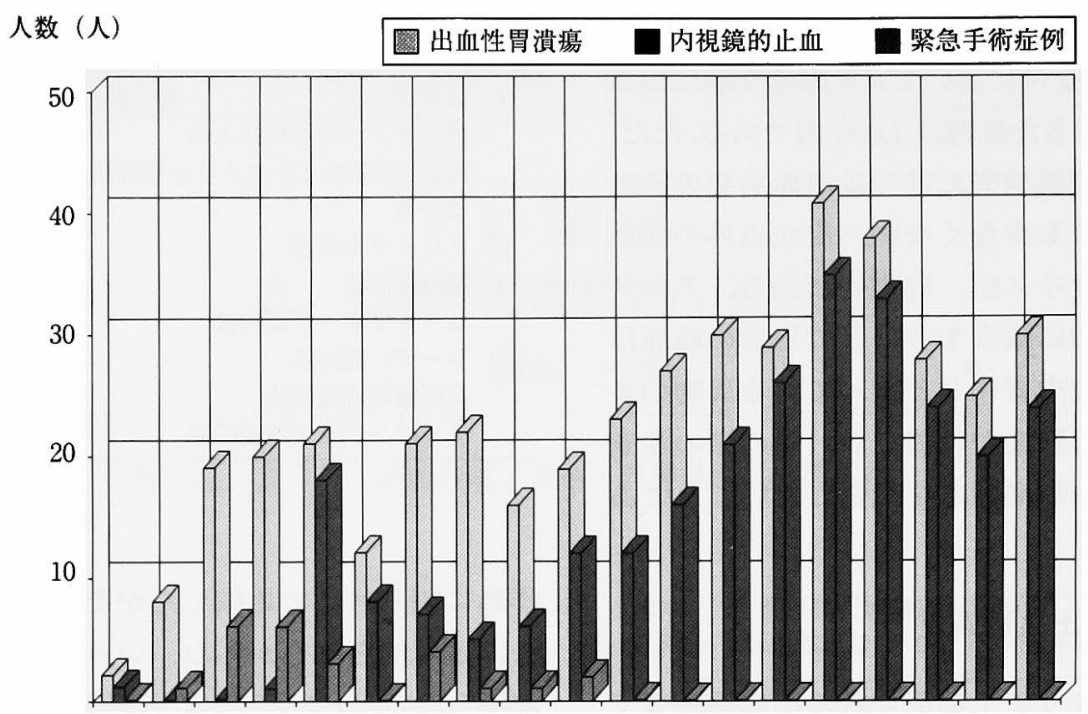

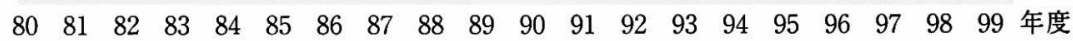

図 1. 佐賀医科大学附属病院における出血性胃潰瘍患者の年次推移(文献 (1)より改変 して引用).

表 4 、胃潰瘍の露出血管へのエタノール局所注入法 の再出血予防効果（文献 2 を改变して引用）

\begin{tabular}{c|c}
\hline エタノール局所注入法 & トロンビン散布のみ \\
\hline $\begin{array}{c}\text { 再出血率 } \\
4 / 29(12.1 \%)^{*}\end{array}$ & $10 / 29(34.5 \%)$ \\
\hline
\end{tabular}

$*=\mathrm{P}<0.05$

の慢性潰湯ではいったん自然止血した潰瘍で検 討してみると，その再出血率は胃に比較して再 出血を起こしにくいことが判明しだ). 潰瘍底所 見が非出血性露出血管あるいは凝血付着の症例 ではエピネフリンとトロンビンの撒布法を行う だけでも, 非出血性露出血管あるいは凝血付着 症例の再出血率をみると, それぞれ 18 例中 1 例, 13 例中 2 例と低率にとどまっていた3)．しかしな がら, 球部の潰瘍と異なり球後部から十二指腸 下行脚の出血性潰痬となると再出血例や止血困 難例が多く, その特徴としては急性潰瘍の性状 を持ち多発する傾向があり, 重篤な基礎疾患を 有する患者に多いことがあげられた1．

十二指腸潰瘍と同様に胃潰瘍での止血困難例
や予後不良例を検討した ${ }^{1)}$. 佐賀医科大学附属病 院で出血性胃潰瘍にて手術になった 12 症例で検 討してみると, 胃角部から胃体部の小弯・後壁 に存在する動脈性出血を呈する重症の症例が多 く,このなかには 3 例のDieulafoy潰瘍が含まれ ていた.このような症例は内視鏡止血治療が開 始された初期の時代の症例に多く, 最近では内 視鏡機器の改善等でその頻度は減少してきてい る.アルゴンプラズマ凝固法はイオン化された アルゴンガスを介して高周波電流で組織を凝固 する方法であり, 非接触性で正面視できない病 変にも均一で広範囲の凝固が可能で上記のよう な症例には有用である.しかし，どうしても止 血できない時や再出血を繰り返す症例もあり緊 急手術の可能性はいつも考えておく必要がある. 内視鏡止血後の一カ月以内に死亡した症例は重 篤と考えられる基礎疾患を有し，死亡原因にも 基礎疾患が関与していた。

2）出血性食道・胃静脈瘤に対する止血術

出血性の静脈瘤に対してはかつてはバルーン タンポナーデ法や薬物療法の対症療法や緊急手 


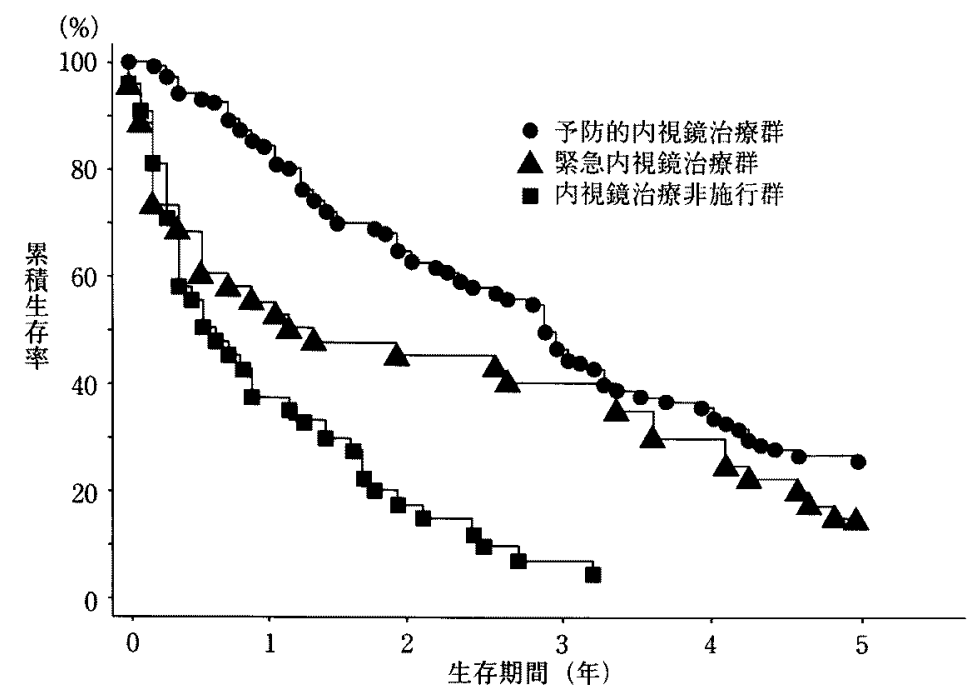

図 2、肝臓癌合併肝硬变に対する食道静脈㾇治療成績を生存率で比較検討(文献(5)よ り改変して引用)。

術で対応していたが，本邦においては今日では 緊急内視鏡検査による内視鏡止血療法が広く行 われる.内視鏡止血術としては内視鏡的硬化療 法と内視鏡的静脈瘤結禁療法があるが, 最近で はその簡便さから静脈瘤結紫術で一次止血をし ている施設が多く，再発例等で結紮術では止血 困難例に硬化療法で一次止血している，静脈瘤 結紫術単独での治療は再発が多いという久点が あり ${ }^{4)}$ ，多くの施設では結紫術で一次止血後は硬 化療法を追加して永久止血をしているのが現状 である。

佐賀医科大学附属病院での静脈瘤に対する内 視鏡的治療の成績を図 2 に示した ${ }^{5}$. 肝臓癌と肝 硬変を合併した食道静脈瘤患者で検討している. バルーンタンポナーデや薬物療法だけの対症療 法で対応した群に比較して, 急性出血群で緊急 内視鏡治療をした群での 5 年生存率は有意に高 く，さらに予防的内視鏡治療群ではさらに高い 5 年生存率が得られた. しかし, 肝機能が著しく 低下している症例や肝臓癌の予後の悪い症例や 門脈に腫瘍塞栓のある患者では急性出血に内視 鏡止血術を行なっても生存予後の改善はあまり
期待できないのが塞際である。

胃の静脈瘤は食道に比較して血流が速く止血 が困難で，その対処法は本邦においても施設に よって異なっている. 佐賀医科大学附属病院で はcyanoacrylateによる硬化療法で対応している. 関連病院においては結禁術で一次止血して佐賀 医科大学附属病院に搬送し硬化療法をすぐに施 行している.

3）その他の出血性病変に対する止血術

Mallory-Weiss症候群による出血で重症例では 緊急手術になる症例もあったが，内視鏡的にク リップによる止血が可能となり，クリップによ る縫縮止血が施行されるようになった，逆流性 食道炎からの出血は大量となることは稀で内視 鏡処置よりもプロトンポンプ阻害㘊による治療 等で対応する，逆流性食道炎では出血よりもむ しろ狭窄が問題となることがあるが，この場合 はバルーン等の内視鏡的拡張術で対応が可能で ある．胃炎や急性胃粘膜病変の止血は潰瘍に対 する止血法に順ずるが，広範囲からの出血の場 合にはアルゴンプラズマ凝固法が有用である. 悪性腫瘍からの出血の頻度は高くないが, 出血 
に対して内視鏡的止血術だけでは対応できない 場合は緊急手術やinterventional radiologyが必 要となる.

まとめ

内視鏡による治療技法の発達と共に緊急内視 鏡検查が皘極的に施行されるようになり，上部 消化管の救急を要する病変への迅速な診断と治 療が可能となってきている，消化管出血に対し ては，その多くが内視鏡的に止血が可能となっ ているが，内視鏡検査までの初期対応や内視鏡 的に止血できない症例への対応等, 救急, 外科, 放射線科等の他科との連携も重要となっている. 消化管内視鏡検査は，繁急内視鏡検查の分野た けでなく消化管腫㴦の内視鏡的切除，消化管ス テントの挿入，胆道系の処置等を含めて診断面 だけでなく治療面でも不可欠なものとなってお り，ょり専門性の問われる手技となっている.

\section{文献}

1）小山孝則, 他：内視鏡止血困難あるいは生命予後不良の 出血性溃癔に関する㭘討，当院における14年間の緊急内 視鏡症例の分析. 日消内誌 $39: 10-18,1997$.

2) Koyama $T$, et al: Prevention of recurrent bleeding from gastric ulcer with a nonbleeding visible vessel by endoscopic injection of absolute ethanol: a prospective, controlled trial. Gastrointest Endosc $42: 128-131,1995$.

3) Koyama. T, et al : Risk for rebleeding of the duodenal bulbar ulcer is less than that of the gastric ulcer. Am J Gastroenterol 91 : 1290-1291, 1996.

4) Gotoh $Y$, et al : Evaluation of endoscopic variceal ligation in prophylactic therapy for bleeding of oesophageal varices : a prospective, controlled trial compared with endoscopic injection sclerotherapy. J Gastroenterol Hepatol $14: 241244,1999$.

5) Iwakiri $R$, et al : Endoscopic injection sclerotherapy for esophageal varices prolonged survival of patients with hepatocellular carcinoma complicating liver cirrhosis. Gastrointest Endosc 51 : $569-572,2000$. 